\title{
COMPANY FINANCIAL FLOW MODELLING BY SYSTEM DYNAMICS METHODOLOGY
}

\author{
Dmytro ZHERLITSYN@1*, Liudmyla GALAIEVA®2 ${ }^{2}$, Volodymyr MANDRA@3 \\ 1,2 Department of Economic Cybernetics, Faculty of Information Technologies, National University \\ of Life and Environmental Sciences of Ukraine, Heroiv Oborony Str. 15, 03041 Kyiv, Ukraine \\ ${ }^{3}$ Sea Commercial Port "Yuzhny”, Beregova Str. 13, 65481 Yuzhny, Ukraine
}

Received 28 February 2021; accepted 01 April 2021

\begin{abstract}
Purpose - the purpose of the article is to develop a conceptual model of the company's financial logistics based on the system dynamics principles.

Research methodology - the article is based on the system analysis and system dynamics methods to define, classify and simulate a company financial flow.

Findings - the definition of financial logistics for a business system has been defined. The authors make a classification of the company's financial flow by the main economic activities and time series factors.

Research limitations - commercial data, used for the practical implementation of the model, are confidential and cannot be disclosed.

Practical implications - the model is implemented by transformation of a system dynamic flow graph into VENSIM programs. It may estimate the stationary trajectory financial flow and short-term and long-term gaps.

Originality/Value - the conceptual model of the company's financial logistics is determined based on the system dynamics principles. The model includes the advantages of the financial management methods and contemporary econometric analysis instruments based on a system dynamics.
\end{abstract}

Keywords: financial management, company, financial flow, financial logistics, simulation, system dynamics.

JEL Classification: G17, G32, C53, C63.

Conference topic: Contemporary Financial Management.

\section{Introduction}

An economic activity is closely connected with domestic, regional and international financial flows, financial risks and the probability of current debt, etc. Thus, the dynamic of financial resources gaining and spending at all stages of the production and commercial cycle and the synchronization of relevant processes in time and space is the basis for determining and maintaining the business stability. The situation has become more complicated in recent years when market priorities are rapidly changing. The intense international competition and digitalization, and production cycles requires constant renewal. The performance of companies in the production and service sectors becomes dependent on the effectiveness of the financial management system. Therefore, the company financial flow has been a contemporary issue of scientific research and practical activities (Karpenko et al., 2020; Mandra, 2018).

In addition to the general business efficiency support in product and service flows, the financial activities become a separate control object. The financial logistics for the company cash flow management are the objects of the business and scientific research (Bowersox et al., 2002; Wang et al., 2008; Mandra, 2018).

However, the financial logistics flow of a company (enterprise, corporation, business unit) is a complex dynamic management system. Traditional methods of financial planning do not take into account the relationship of all the dynamic components of the company financial flow. The financial management of a company must take into account the systemic characteristics and dynamic relationships of all economic units and business processes.

*E-mail: dzherlitsyn@gmail.com

(C) 2021 Authors. Published by Vilnius Gediminas Technical University. This is an open-access article distributed under the terms of the Creative Commons Attribution (http://creativecommons.org/licenses/by/4.0/) License, which permits unrestricted use, distribution, and reproduction in any medium, provided the original author and source are credited. 
Many of previous research and business practices on the cash flow management and modeling have identified the specific phenomena of holistic financial flow as an object of regulation and value-added creation. Therefore, the mathematical and system dynamics models, contemporary information technologies should be used in a complex to obtain value preservation and increase business profit.

The purpose of the study is to develop a conceptual model of the company financial logistics based on the system dynamics principles.

Related works. The cash and financial flow management system is the research object for various scientists, economists, and financial managers. In particular, in classical studies on cash flow management (De Moraes et al., 2019; Kazakova et al., 2018; Zherlitsyn et al., 2019), the essence and principles of financial management, the specifics of economic activity, measurement of the level of financial risks, analytical and organizational procedures for cash flow optimization have been discussed. However, the classical approach to financial flow management is based on static information of financial accounting or separate dynamic assessments. It does not allow for adequate reaction on financial and economic changes.

On the other hand, finance is an integral part of any business system and logistics process. In classical studies of the theory of logistics and supply chain optimization (Bowersox et al., 2002; Wang et al., 2008), financial flow is considered as a process of movement of auxiliary resources. However, the financial flow can also be considered as a separate object of regulation, which further confirms the relevance of the improvement and development of financial logistics tools in the business management system.

Simulation models have been widely applied to cash flow management and logistics process regulation. There are two methodology directions for the simulation model application. The first, a discrete simulation and econometric analysis of time series data, in particular the simple Monte-Carlo approach. The second, cash flow management, which is based on system dynamics methodology.

Econometrics approach is based on a cash flow dynamic history (Baranovskyi et al., 2019; Skrypnyk et al., 2020) and concentrated on estimation stochastic forecasting (Huang et al., 2013; Krumrey et al., 2018; Tangsucheeva \& Prabhu, 2014). The related articles are devoted to the econometric analysis of financial flow, forecasting fluctuations in predicted estimates. However, these works do not take into account the impact of fundamental business dynamics on financial flow.

The system dynamics methodology is widely used for solving different problems in logistics and management purpose. In particular, the system dynamics methodology is used to simulation and forecasting financial flow in supply chain (Sana et al., 2018). This approach is to synchronizing material and financial flow, but it is does not sufficiently detail the dynamics of the financial flow. The supply chain management and cash conversion cycle are the objects of generic material stock and flow model for a member (Badakhshan et al., 2020). They show the bullwhip effect for cash flow, but not fully address the other part of the financial flow.

Research method used. The system dynamics thinking and modelling essentially consist of problem statement, causal loop diagram, stock-flow diagram, scenario planning and modelling, implementation and organization learning. The steps for modelling and simulating of complex systems are (Bala et al., 2017; Broy, 2014; Kofjac et al., 2003; Kozlovskyi et al., 2020):

- identify the problem;

- develop a dynamic hypothesis explaining the cause of the problem;

- create a basic structure of a causal graph;

- augment the causal graph with more information;

- convert the augmented causal graph to a system dynamic flow graph;

- translate a system dynamic flow graph into SD programs (VENSIM, STELLA, Anylogic) or equations.

The implementation of the system dynamics methodology involves the use of the following types of variables (Bala et al., 2017; Broy, 2014; Kofjac et al., 2003; Kozlovskyi et al., 2020):

- LEVEL or STOCK indicates a cumulative level of the dynamic flow;

- AUXILIARY is used for auxiliary parameters estimation;

- RATE realizes function for input and output for the LEVEL variable;

- CONSTAT shows fixed or adjustable parameters.

Practical result of the System Dynamics model is the forecast of the level variables within the impacts of regulated constants. The forecast is developed as a result of a set of iterations. Therefore, the main modeling steps for this paper are: to create a basic structure of a causal graph and translate a system dynamic flow graph into VENSIM programs. The practical step can be applied in further research. 


\section{Company's financial management and financial logistics}

The specifics of company financial flow management are determined by the following features of their main activity (Mandra, 2018):

- operational, investment and financial activities are discovered as a structural parts of the company financial flow management system;

- additional attention is paid to the possibility of attracting credit resources, using of temporarily free funds, purchasing of materials, etc.;

- continuity of operational processes and participation in consolidated supply chains, which increases the longterm liabilities under difficult economic conditions.

All these specific features, along with the classic problems of material and financial flows coordination, determine the need and relevance of developments for improving existing managing instruments by using the principles of financial logistics.

Financial logistics, as part of the logistics approach to management, has been considered for a long time. In particular, in the classical theory of logistics, finance is part of the overall system of material flow management (Badakhshan et al., 2020; Sana et al., 2018). However, in some contemporary studies, financial logistics is considered as a specific system of financial flow management, which is not always associated with the movement of material resources, namely, within consolidated groups of enterprises (Mandra, 2018) and so on.

Taking into account the specifics of contemporary business system, the financial flow, as a holistic object of management, should be considered as a set of the following subsystems (Zherlitsyn et al., 2019; Yu, 2015):

- operational activities for the provision of basic production and service;

- operational activities for the provision of related services (for example, transport, logistics, financial services);

- investment activity and creating the long-term asses within the ability to produce the value-added of investment capital;

- financial activities and capital management as a part of a long-term strategic management system;

- operations for managing cash flow and short-term liabilities for supporting the operational, investment, and financial activities in a condition of different kind of delays.

Therefore, it is advisable to develop new and improve existing tools for managing the company financial flow by using the methods of logistics management, system-dynamic modeling, and information-analytical support for management decisions.

\section{Company financial flow simulation}

\subsection{System dynamics model conceptualization}

The principles of financial logistics and system dynamics methodology determine the need to formulate basic level models. Therefore, the basic variables and dependencies of the system-dynamic of company financial logistics model have the following essential values (Table 1).

The rate variable $C V F_{t}$ is related to the other rate and stock variables, namely: Variable Operational Costs $\left(V O C_{t}\right)$, working capital $\left(C_{t} \cdot W C R\right.$, where $W C R$ - working capital rate as an adjustable constant) and Long term assets $\left(\right.$ LTA $\left._{t}\right)$ and investment multiplier (RID, Daily return on investment). Therefore, the Creating Value Function is a production function with certain adjustments. In particular, its results are: Sales $\left(S_{t}\right)$, Variable Operational Costs $\left(V O C_{t}\right)$.

There are following dynamic dependencies for the level variables of the company financial logistics model.

1. Capital of a company $\left(C_{t}\right)$ and long-term liabilities $\left(L T L_{t}\right)$ are initiated by the equity and non-current liabilities. Their dynamics defined as follows:

$$
\begin{gathered}
\frac{d C}{d t}=I C(t)-C D(t), \frac{d L T L}{d t}=C R I(t)-C R O(t), \\
I C_{t}=M I N\left(B F P, C R I_{t}+O P L_{t}\right), C D_{t}=C R O_{t}, \\
C R I_{t}=\left(C_{t}+L T L_{t}\right) \tau, C R O_{t}=L T L_{t} \cdot \gamma, \\
L C_{t}=L T L_{t-1} \cdot r_{c r}+S T L_{t-1} \cdot r_{s r l},
\end{gathered}
$$

where: $\gamma$ - daily rate of long-term liabilities repayment; $L C_{t}$ - fixed costs for liabilities use; $r_{c r}, r_{s r l}$ - previously estimated (fixed) credit rates for different types of liabilities; $\tau$ (Credit Share) - percentage of the long-term liabilities in the capital structure as an adjustable constant; BFP - (Budget Financing Plan) budget constraints, which are determined by the company's financial plan (an adjustable constant). 
D. Zherlitsyn, L. Galaieva, V. Mandra. 2021. Company financial flow modelling by system dynamics methodology

Table 1. Core variables of the company financial logistics model (source: developed by the author)

\begin{tabular}{|c|c|c|}
\hline Variable & $\begin{array}{l}\text { Symbol for } \\
\text { VENSIM notated } \\
\text { variable }\end{array}$ & Definition \\
\hline$C V F_{t}$ & $\begin{array}{l}\text { Creating Value } \\
\text { Function }\end{array}$ & $\begin{array}{l}\text { Function that formalizes the conditional process of "production" (product creation, service } \\
\text { delivery, etc.). It summarizes the results of all operational activities }\end{array}$ \\
\hline$C_{t}$ & Capital & $\begin{array}{l}\text { Level of company capital which increases by profit and loans; and reduces by losses, long- } \\
\text { term liabilities repayment, other capital losses }\end{array}$ \\
\hline$L T A_{t}$ & Long term assets & $\begin{array}{l}\text { Long-term assets that affect the level of return on resource used. It is increased by the } \\
\text { provided investments and decreased by the depreciation of assets (fixed costs) rates }\end{array}$ \\
\hline$I L_{t}$ & Investment level & The amount of investments provided by the company in accordance with its development plan \\
\hline$C F_{t}$ & Cash Flow & $\begin{array}{l}\text { Cash flow level and its liquidity equivalents. This is a key indicator of the model, which } \\
\text { increases as a result of operational activity (Sales Flow), the capital increase (Capital Flow), } \\
\text { and decreases by the financial of operational costs (Operational Flow), investment costs } \\
\text { (Investment Flow) and interest payments (Financial Flow) }\end{array}$ \\
\hline$S T L_{t}$ & Sort term liabilities & $\begin{array}{l}\text { Level of planned but not financed investments, which increases by the negative Cash Flow } \\
\text { rate and decreases by the excess Cash Flow }\end{array}$ \\
\hline$L T L_{t}$ & Long term liabilities & Level of the long-term liabilities (bank credit, loan etc.) \\
\hline$I C_{t}$ & Increase of capital & Daily capital increase rate \\
\hline$C D_{t}$ & Capital decrease & Daily capital decrease rate \\
\hline$C I_{t}$ & Cash In & Daily Cash Flow increase rate \\
\hline $\mathrm{CO}_{t}$ & Cash Out & Daily Cash Flow decrease rate \\
\hline$\overline{D E_{t}}$ & Depreciation & $\begin{array}{l}\text { Daily depreciation rate of the long-term-assets. It determinates the level of the company Fixed } \\
\text { Operational Costs by used assets }\end{array}$ \\
\hline$U I F_{t}$ & $\begin{array}{l}\text { Using investment } \\
\text { funds }\end{array}$ & $\begin{array}{l}\text { Daily financed investment rates which increase the level of investment assets and the value of } \\
\text { long-term assets }\end{array}$ \\
\hline$I P_{t}$ & Investment plan & Assessment rate of daily increase in the investments \\
\hline$I C_{t}$ & Investment Costs & Assessment rate of daily decrease in the investments \\
\hline$P I_{t}$ & Payable In & Daily short-term liabilities increase rate \\
\hline $\mathrm{PO}_{t}$ & Payable Out & Daily short-term liabilities decrease rate \\
\hline$C R I_{t}$ & Credit In & Daily long-term liabilities increase rate \\
\hline $\mathrm{CRO}_{t}$ & Credit Out & Daily long-term liabilities decrease rate \\
\hline
\end{tabular}

2. The long-term assets $\left(L T A_{t}\right)$ is defined by its initial level and dynamics as follows:

$$
\begin{gathered}
\frac{d L T A}{d t}=U I F(t)-D E(t), \\
U I F_{t}=I F_{t}, D E_{t}=\alpha \cdot L T A_{t-1},
\end{gathered}
$$

where: $\alpha$ - daily rate of cost transfers from the use of long-term assets.

3. The cash flow $(\mathrm{CFt})$ and associated level of the short-term liabilities $\left(S T L_{t}\right)$ are calculated as follows:

$$
\begin{gathered}
\frac{d C F}{d t}=C I(t)-C O(t), \frac{d S T L}{d t}=P I(t)-P O(t), \\
C I_{t}=S F_{t}+C I F_{t}, C O_{t}=O F_{t}-P O_{t-1}+P I_{t-1}, \\
P I_{t}=-M I N\left(0, C F_{t-1}\right), \\
P O_{t}=\operatorname{MIN}\left(\operatorname{MIN}\left(\beta, C F_{t-1}-C O_{t-1}\right), S T L_{t}\right),
\end{gathered}
$$

where: $\beta$ - minimum amount of the Cash Flow variable (ensuring a minimum level of liquidity).

The other variables are used as auxiliary and adjusting parameters of the company financial logistics model.

In particular, indicators of delays in the implementation are determined by the following adjusting constants of the model:

Delay in payment 1 - delay in receivables;

Delay in payment 2 - delay in payables;

Delay in payment 3 - delay in receivables from capital increase;

Delay in payment 4 - delay in settlements under the investment obligation; 
Return on investment Delay - a delay that affects the return on investment (the period of accumulation of investment potential, for example, completion of construction of berths or their re-equipment, commissioning of equipment, etc.).

Therefore, the company financial logistics model is devoted to simulating and forecasting cash flow and short-term liabilities level dynamics for operational, financial, and investment activities within the different financial logistics delays.

\subsection{Causal relationships for the company financial logistics purpose}

The construction of the company financial logistics model is determined by the relevant strategic guidelines, in particular, the maximization of gross revenues or operational profit. Further operational destabilization of relevant strategic indicators shows the need to study and model the dynamics of gross profit by optimizing revenues (by type of activity), costs (operating leverage, logistics costs and time delays, etc.) and working capital turnover, average cost, working capital leverage, etc. The investment and financial subsystems of the model provide information on the dynamics of capital (weighted average cost of capital, profitability, etc.) and profit (financial leverage, loss or profit, the size of penalties and regulatory costs).

Taking into account the specified features of financial flow management processes and methodology of system-dynamic simulation (Bala et al., 2017; Broy, 2014), the causal diagram of relations of the corresponding model of the company financial logistics is presented on Figure 1. Symbols of graphic elements, presented in Figure 1, are given in Table 1 and in previous research.

Figure 1 shows that in the short term the relationship between the indicators of current liabilities (Short term liabilities) and assets (Short term assets), which are the regulatory variables and are defined as the difference between the actual value of operational, investment, financial flow, and the capital and income flow together with their financed part. In addition, the use of the proposed system-dynamic model of company financial logistics allows to determine the plans of financial flow and to carry out their operational refinement. The simulation process consists of the next stages. The first stage: initial value of the Delay constants and Level variables are set. The second stage: the iteration process starts. In the iteration stage, the levels of Cash Flow and Sort term liabilities are stabilized. The third stage: a series of consistent iterations are produced. The average levels of the main variables and delays time are being estimated. The result is the input indicators of the company's financial flow plan.

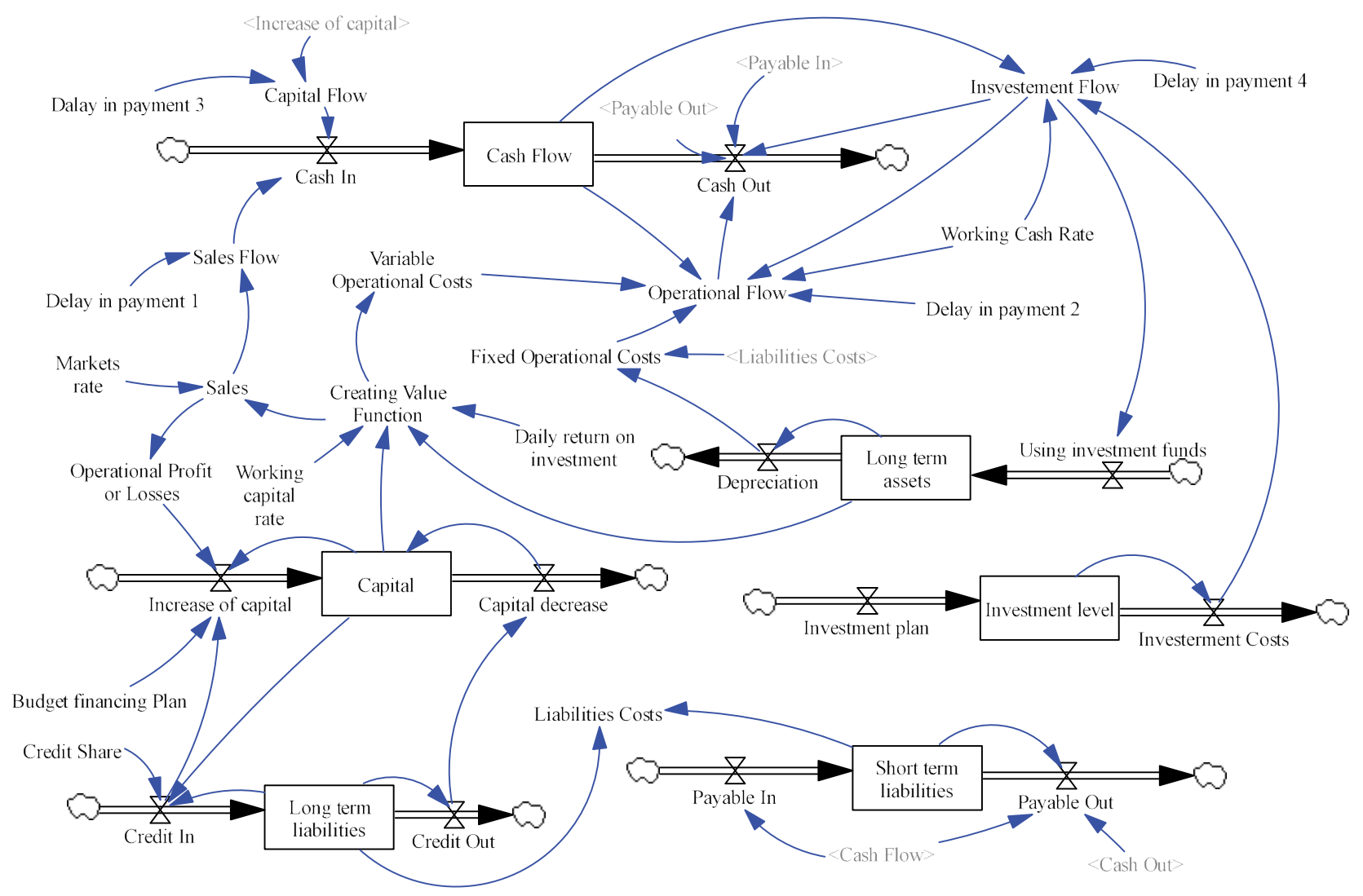

Figure 1. Causal Diagram of the company financial logistics model (source: developed by the author based on system dynamics methodology Bala et al., 2017) 


\subsection{Organization direction for the model implementation}

In order to implementate the company's financial logistics model, to streamline the relations, to clarify the work performed, to improving the organization of work in terms of managing the processes of company financial logistics, the division of responsibilities and powers of key organizational units is presented.

Director approves the general procedure for managing financial flow, organization of financial logistics processes, and changes to it.

Deputy Director on Economics and Finance determines strategic indicators for assessing the efficiency and effectiveness of company financial logistics processes, undertakes the general control over the receipt and expenditure of funds. He is also responsible for financial documents.

Chief Accountant provides operational control of financial flow, calculations, adjusts current changes in the financial flow plan, and makes recommendations for improving the processes of accounting and reporting in general.

These structural units are responsible for the approval and implementation of the already approved financial flow plan. The following structural units are responsible for operational formalization and optimization of financial flow for all types of activities (according to the model results).

The financial department is a key link in the system of management of the company financial logistics processes, namely:

- generalizing information from various sources (internal, external);

- formalizing strategic, tactical, and operational tasks for financial flow management;

- monitoring the implementation of the approved plan of revenues and expenses;

- determining the need for adjusting the financial flow plan, etc.

Procurement Department monitors compliance with the contracts' terms. Within the system of financial logistics, it is responsible for the generalization and formalization of terms of settlements under contractual obligations, determination of procurement criteria, and regulatory deadlines for their commissioning.

Perspective Investment and Strategic Analysis Department determines the directions of company investment activity, controls the execution of payments under the concluded investment agreements, forms registers of payments on investment activity, etc. Within the framework of the presented approach, this department is responsible for the generalization and formalization of information on investment plans, terms of commissioning of new assets, and determination of planned efficiency of their use.

Other elements of organizational structure of the financial and economic activity management system of the company are also incorporated into the process of financial flow management by providing the formation of reports on material resources, actual completion of service processes, possible delays, and deviations from planned values due to technical, organizational, and other factors.

\section{Conclusions}

The improvement of the company financial flow management processes, based on the principles of the logistic approach to the regulation of economic processes, is an essential task of contemporary theory and practice of business management. At the same time, the company financial logistics system, being a specific element of the company's activity, is determined by the specific of cash flow and liabilities management, in particular, special consideration is given to types of business activities, supply chain delays, complexity, and multi-stage operational processes.

As a result of the research, a system-dynamic model of company financial logistics is proposed. It combines the advantages of a systematic approach to the management of economic processes and contemporary tools of econometric and financial analysis. The tasks and responsibilities of the management to implement the proposed model within the company's organizational structure are determined.

This model provides significant advantages over the classical financial management methods. There is an opportunity to evaluate several scenarios of financial flow dynamics at once. It allows to analyze the mutual influence between economic, financial and investment flows. The dynamic dependence of cash flows and the effectiveness of assets are evaluated. Thus, the use of the system-dynamic model of company's financial logistics allows to reduce the cost of the financial planning system and increase the accuracy of financial forecasts.

The scientific results are a starting point for further research of contemporary approaches to the company financial flow management, in particular, in the form of building applied simulation models for different spheres of economic.

\section{Author contributions}

Zherlitsyn D. has formulated the company financial logistics model and the concept of financial logistics, Galaieva L. has translated a system dynamic flow graph into VENSIM programs, Mandra V. has introduced organizational features of the results. 


\section{Disclosure statement}

The authors declare that they have no relevant or material financial interests that relate to the research described in this paper.

\section{References}

Badakhshan, E., Humphreys, P., Maguire, L., \& McIvor, R. (2020). Using simulation-based system dynamics and genetic algorithms to reduce the cash flow bullwhip in the supply chain. International Journal of Production Research, 58(17), 5253-5279. https://doi.org/10.1080/00207543.2020.1715505

Bala, B. K., Arshad, F. M., \& Noh, K. M. (2017). Systems thinking: system dynamics. In System dynamics: modelling and simulation. Springer. https://doi.org/10.1007/978-981-10-2045-2 2

Baranovskyi, O. I., Kuzheliev, M. O., Zherlitsyn, D. M., Sokyrko, O. S., \& Nechyporenko, A. V. (2019). Econometric models of monetary policy effectiveness in Ukraine. Financial and Credit Activity-Problems of Theory and Practice, 3(30), 226-235. https://doi.org/10.18371/fcaptp.v3i30.179546

Bowersox, D. J., Closs, D. J., \& Bixby Cooper, M. (2002). Supply chain logistics management (Vol. 2). McGraw-Hill.

Broy, M. (2014). A model of dynamic systems. In S. Bensalem, Y. Lakhneck, \& A. Legay (Eds.), Lecture notes in computer science: Vol. 8415. From programs to systems. The systems perspective in computing (pp. 39-53). Springer.

De Moraes, C. O., Antunes, J. A. P., \& Rodrigues, A. (2019). Financial intermediation analysis from financial flows. Journal of Economic Studies, 46(3), 727-747. https://doi.org/10.1108/JES-10-2017-0302

Huang, W. H., Tserng, H. P., Liao, H. H., Yin, S. Y. L., Chen, P. C., \& Lei, M. C. (2013). Contractor financial prequalification using simulation method based on cash flow model. Automation in Construction, 35, 254-262. https://doi.org/10.1016/j.autcon.2013.05.004

Karpenko, L., Chunytska, I., Oliinyk, N., Poprozman, N., \& Bezkorovaina, O. (2020). Consideration of risk factors in corporate property portfolio management. Journal of Risk and Financial Management, 13(12), Article 299. https://doi.org/10.3390/jrfm13120299

Kazakova, H., Zayarsky, I., \& Medvedev, M. (2018, September 13-18). Forecasting of financial flows in business systems taking into account the risk and uncertainty of interaction [Conference presentation]. International Conference on Numerical Analysis and Applied Mathematics (ICNAAM-2018), Rhodes, Greece.

Kofjac, D., Skraba, A., \& Kljajic, M. (2003). Neural network modeling by system dynamics methodology - Basic concepts. In IEEE Region 8 Eurocon 2003. Computer as a Tool (pp. 424-428), Ljubljana, Slovenia. IEEE. https://doi.org/10.1109/EURCON.2003.1248057

Kozlovskyi, S., Bilenko, D., Kuzheliev, M., Lavrov, R., Kozlovskyi, V., Mazur, H., \& Taranych, A. (2020). The system dynamic model of the labor migrant policy in economic growth affected by COVID-19. Global Journal of Environmental Science and Management, 6, 95-106. https://doi.org/10.22034/gjesm.2019.06.si.09

Krumrey, L., Moeini, M., \& Wendt, O. (2018). A cash-flow-based optimization model for corporate cash management: a Monte-Carlo simulation approach. In N. T. Le, T. van Do, N. T. Nguyen, \& H. A. Le Thi (Eds.), Advances in intelligent systems and computing: Vol. 629. Advanced computational methods for knowledge engineering (pp. 34-46). Springer. https://doi.org/10.1007/978-3-319-61911-8 4

Mandra, V. V. (2018). Modernizatsiia protsesiv upravlinnia morskym torhovelnym portom: metodolohiia, modeli ta metody [Modernization of sea trade port management processes: methodology, models and methods]. PUET (in Ukrainian).

Sana, S. S., Ferro-Correa, J., Quintero, A., \& Amaya, R. (2018). A system dynamics model of financial flow in supply chains: a case study. Rairo-Operations Research, 52(1), 187-204. https://doi.org/10.1051/ro/2017025

Skrypnyk, A. V., Klimenko, N. A., \& Kostenko, I. S. (2020). The formation of digital competence for the population as a way to economic growth. Information Technologies and Learning Tools, 78(4), 278-297.

Tangsucheeva, R., \& Prabhu, V. (2014). Stochastic financial analytics for cash flow forecasting. International Journal of Production Economics, 158, 65-76. https://doi.org/10.1016/j.ijpe.2014.07.019

Wang, Y., Yu, D.-L., Peng, Y.-L., \& Hao, H.-Y. (2008, October). Supply chain system financial logistics funds balance of supply and demand based on the system dynamics. In 4th International Conference on Wireless Communications, Networking and Mobile Computing (pp. 1-5), Dalian, China. IEEE. https://doi.org/10.1109/WiCom.2008.1607

Yu, C. P. (2015). Financial policies on firm performance: The US insurance industry before and after the global financial crisis. Economic Modelling, 51, 391-402. https://doi.org/10.1016/j.econmod.2015.08.029

Zherlitsyn, D., Levytskyi, S., Mykhailyk, D., \& Ogloblina, V. (2019). Assessment of financial potential as a determinant of enterprise development. In Proceedings of the 6th International Conference on Strategies, Models and Technologies of Economic Systems Management (pp. 212-216). Atlantis Press. https://doi.org/10.2991/smtesm-19.2019.42 